\title{
136 創造設計教育に関する研究
}

\section{Study on Creative Design Education}

\author{
○設正 三隅雅彦 機·設正 朝比奈奎一 機·設正 平野利幸(都立産技高専） 岡村 大（設計テックス）
}

Masahiko MISUMI, Tokyo Metropolitan College of Industrial Technology, 1-10-40,

Higashiohi, Shinagawa-ku, Tokyo

Keiichi ASAHINA, Tokyo Metropolitan College of Industrial Technology

Toshiyuki HIRANO, Tokyo Metropolitan College of Industrial Technology Hajime OKAMURA, SEKKEI TECHS.,LTD

\section{1.はじめに}

東京都立産業技術高等専門学校ものづくり工学科では, 1998 年より $\mathrm{CAD} / \mathrm{CAM}$ システムやラピッドプロトタイピ ング, リバースエンジニアリング等の機器を導入し， 3 次 元 $\mathrm{CAD}$ 中核としたもの作り教育を行っている ${ }^{1)}$. 第 1 学 年では、手書き製図と平行して 2 次元 $\mathrm{CAD}$ をカリキュラ ムに組み込み，生産システム工学コースに進級した第 2 学 年以降では， 2 次元・3 次元 $\mathrm{CAD}$ を利用した製図とモデ リング実習を行っている.このような第 1 学年から第 4 学 年までの連続したカリキュラムによって，第 5 学年の学生 は, CADの機能とオペレーションについては, 概ね理解し ている.

また本コースでは，「デザインのわかる機械技術者教育」 を教育目標の一つとして揭げ，平成 23 年度より害施を始 めた。これは，エンジニアリングの最上流に位置するとさ れるスタイリングデザイン（意匠設計）を学ぶ事で，イン ダストリアル・デザイナーの造形（意匠）に対する意味や こだわりばかりでなく，造形を工学的に理解することも目 的としている1).

第 5 学年では, 上述のスキルを最大限に活用した授業と して「3 次元 CAD 設計製図 III」を設定し, 各自が自分の 設計対象に沿い，製品化も視野に入れた「創造設計」に取 り組んでいる.

本稿では，第 5 学年で実施している教育事例を紹介する とともに，学生へのアンケートに基づく教育効果について 報告する．

\section{2. 第 5 学年での設計制図教育}

第 5 学年の 3 次元 CAD 設計製図 III では,「創造設計」 をテーマとして, 福祉機器の基本設計（概念設計）を行い, ポスターおよびプレゼンテーション形式での発表を行った. この授業では，機械設計・製図の知識および 3 次元 CAD を活用した機械設計手法を応用し，さらに，設計対象にお ける問題点を自ら探し出し，解決方法を見いだすことで， 創造的設計力を養うことを目的としている.また 3 次元 $\mathrm{CAD}$ は, 実務での利用方も意識し, 設計や表現のためのツ ール（手段）として位置づけている.

3 次元 CAD 設計製図 III は, 100 分授業を後期 8 回で 行った。学生は、福祉機器に関する情報について各自で調 査を行い, 設計対象を決定した。 なお, 設計対象の例とし て, 団地階段用手引きキャリー, 介護ベッド, 車椅子, 卜 イレ, 入浴機器, 福祉車両などを提示した。

設計作業のポイントとしては，下記の例を挙げた。

(1)現状のものを進化させた仕様にするのか
(2)デザインを全く独創的に進化させるのか

(3)進歩性を追い，高い機能と誰もが思いつかないほどの アイデアをだすのか

(4)現状のものを単純な機能にして, 超コストダウンを図 るのか

(5)現状には無いものを新しく生み出すのか

次に仕様（スペック）については，下記の項目を条件と した.

(1)ものづくりの概念を示すために必要な項目と, それぞ れに対する数值を示す

(2)概念図を手描きによるポンチ絵で示す

毎週の授業の終了時には, 図 1 で示すような「先週の問 題点と解決策」と「次週までに調べておく事」を記入する 授業レポートを提出させた。これにより，週 1 回の授業で あっても，設計作業に連続性を持たせることが可能となり， 学生が主体的に取り組みやすい環境を作ることができる. さらに, 各自が記録した内容は, 作業の後半で制作するポ スターやプレゼンテーションデータを構成する素材となり， 効率的な作業が可能となる。 また， 3 次元 CAD を利用し た設計作業では，画面表示の拡大縮小による実寸の感覚の 低下や，ディティールにこだわりすぎる傾向が見られるた め, 使用を想定している環境や人との関係から設定される 寸法を記入することも条件とした.

ポスターは，設計思想や問題点の抽出から解決策を見い だす過程，構造，使用状況などを的確に表現することを条 件とし、レイアウトデザインは自由とした．

プレゼンテーションは PowerPoint を使用し，発表時間 は一人 5 分（講演 3 分十討議 2 分）とした. 発表終了後に は, 20 分間のポスターセッションタイムを設定し, プレ ゼンテーションで不足した説明や質問を補うものとした.

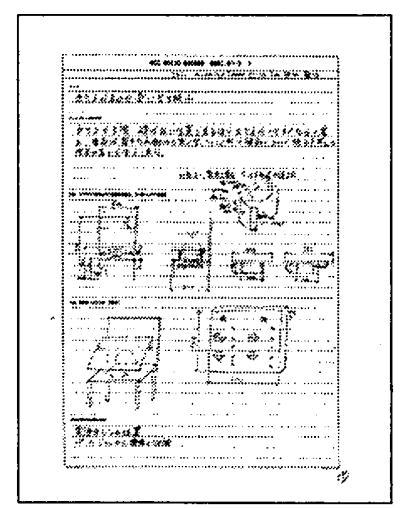

(a)

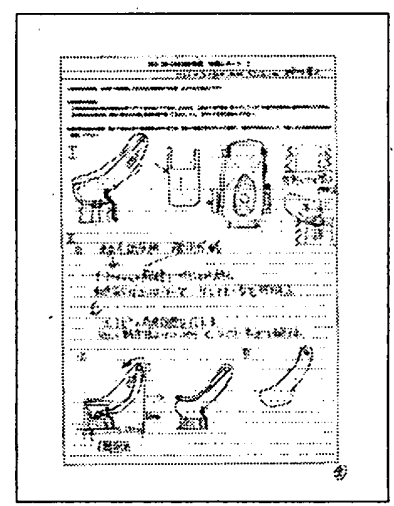

(b)
Fig.1 Lesson report

No. 12-69 技術と社会の関連を巡って：過去から未来を訪ねる〔2012-11.24, 秋田〕 


\section{3. 授業展開}

（1）現状の把握と着眼について

福祉機器や福祉そのものの現状を知ることから始め, 問 題点の掘り起こしから解決策を見いだしていく過程（着眼 のヒント）として，2つ例を挙げた。

(1)動きや構造からの着眼

(2)使用しているシーン（シナリオライティングの設定） による着眼

(1)は，本来であれば，現場に赴き現物を調査・分析する のが必須であるが，今回の授業では，iPad（常設の 50 台）を使って現状把握を行った。

(2)は,「デザインのわかる機械技術者教育」の実践として 筆者の前期授業で講義を行っていたため，今回の授業での 応用を実践した。

(2) 構造について

可動部のある設計では，人力かアクチュエータを使用す るのかを具体的にすることを条件とした。また，学習した 範囲での強度・剛性・重量・重心位置などを計算し, 結果 を明記するものとしたままた，歯車については，柬数を一 致させる事が目的ではなく，構造として成り立っていれば 可とし，アクチュエータも含めてブラックボックス化しな いことを条件とした。

さらに寸法や可動範囲の設定では， 3 次元の人体モデル を使って確認を行わせた。（図 2)

(3) デザインについて

設計対象物の機能と外観処理との関係も設計要素として 考虑することとした。

ポスターは, A3 サイズ縦, カラーで出力した.（図 3 )

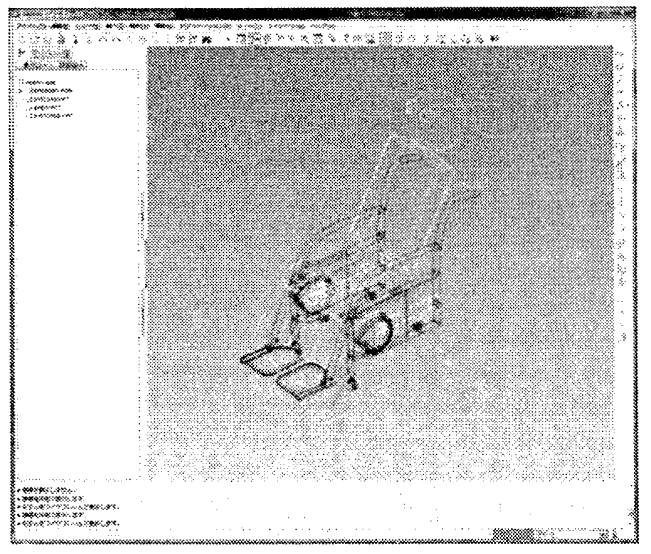

Fig.2 Design by 3D-CAD

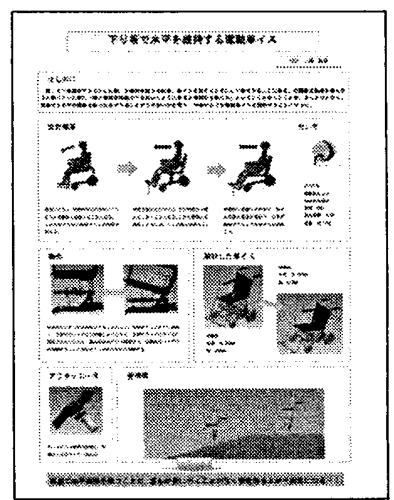

(a)

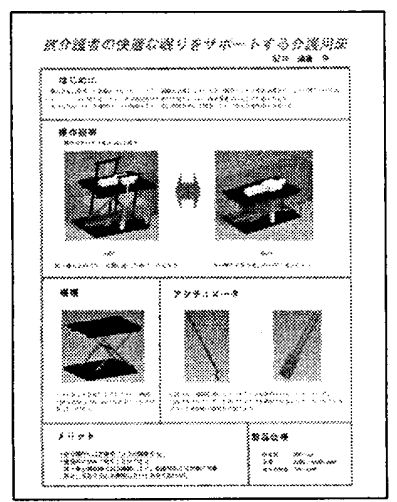

(b)

Fig.3 Poster for presentation

\section{4. 教育成果}

福祉機器を設計対象とした創造設計を通して，どのよう な成果が得られたかを検証するために，この授業を受講し た 38 名の学生に対してアンケートを実施した. 図 4 は創 造設計に関するアンケート結果をまとめたものである.

Q. 問題発見から問題解決までのプロセスが理解できたか.

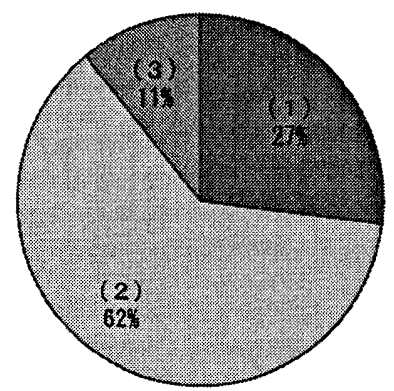

Fig.4 Understanding of the process from problem discovery to problem solving

(1)あてはまる

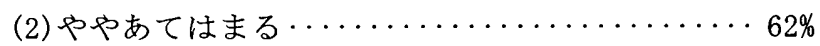

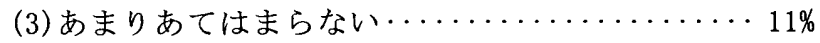

(4)あてはまらない............................

図 4 は, 課題全般の設計プロセスの把握についての回答 である。30\%弱の学生が高い達成感を得ていることがわか った。これは問題発見の過程で, 福祉機器を必要とする人 の生活シーンや環境を早く見つけ出した学生に共通する回 答である。一方， 70\%強の学生がやや低い達成感を示して いるが，動きや構造を中心に着眼したために，設計目標と 人間や使用状況との関係を見出すのに苦労した学生に多く 見られる回答である.

\section{5.おわりに}

本稿では, 東京都立産業技術高等専門学校ものづくり工 学科生産システム工学コースで実施した創造設計教育につ いて紹介した. 4 年間学んだ工学の専門知識を総動員させ, 製品化も視野に入れたオリジナルの設計を行うことは, 学 生にとっては初めての経験であり, ハードルの高い課題で あった.しかし，他の教科を含めて復習し応用することが， 直面する問題を解決する方法であることに気づいたことが， 他のアンケート項目から明らかになった。これらから, 教 科と教科や環境と人，デザインと工学などを関連づけた授 業展開による, 複眼的な解決能力が重要であることがわか った.

\section{参考文献}

1)朝比奈奎一：機械設計教育へのデザイン導入, No.11-56 技術と社会の関連を巡って：過去から未来を訪ねる 講演 論文集，日本機械学会, pp.51-52，（2011） 